that of an antigenic serum or by other modifications of its toxic properties. At all events the discovery of this drug represents an important advance and may be the prelude to greater things.

\section{War-time Lessons for Peace-time Health}

The Minister of Health, Mr. Ernest Brown, speaking at a meeting of the Cambridge University Medical Society on October 21, said that the operation of wartime services is providing a background against which the Ministry is working out ideas for future developments in public health. As regards the Emergency Hospital Service, Mr. Brown said that the old conception of independent general hospitals to serve all purposes has gradually been replaced by a more co-operative scheme in which different hospitals in an inter-dependent group have special centres for different purposes. Problems of the necessary financial arrangements, including the functions of hospital contributory schemes, of the precise place in the schemes of the local authorities, of what central control will be necessary in a hospital area including the districts of several local authorities, and similar details, remain to be worked out in detail.

Referring to the Ministry's plans to introduce mass miniature radiography to discover cases of incipient tuberculosis, Mr. Brown said that a technical committee is preparing advice for the tuberculosis authorities, to which the machines now on order will be supplied, on how the sets can be used to the best advantage. This committee is also making arrangements to train teams to work the sets and considering proposals for recording results of examinations. The procedure will be to take miniature chest radiograms of a section of the population. It is expected that about 4 in every 100 will show abnormalities on the miniature film, and a full-sized chest radiogram will be taken of these and a clinical examination made. Thus the early case is found and treatment can be begun under the best conditions for success. Though the technique of mass radiography should prove a valuable new weapon for the fight against tuberculosis, it is not a panacea; it does not supersede the established technique but rather permits its wider and more hopeful application.

\section{Food Value of the Potato}

ConTrNued success in safeguarding the essential food supply of Great Britain must largely depend on our ability to use still more home-grown foods, particularly potatoes, in place of imported energy foods. On a calorie basis, each four tons of home-grown potatoes used in Great Britain releases the shipping space otherwise occupied by a ton of wheat. Further, potatoes yield 50 per cent more calories per acre than wheat, despite the greater water content of the former crop (78 per cent against 38 per cent for bread). The components for which potatoes are nutritionally notable are iron, vitamin $\mathrm{C}$ and the vitamins of the B-complex. One pound of potatoes provides 330 calories, equivalent to $5 \mathrm{oz}$. of National bread or 11 per cent of the day's requirement for a moderately active man ; $3 \mathrm{mgm}$. of iron, 25 per cent of the day's requirement and equivalent to that of two eggs; 100 I.U. of vitamin $B_{1}, 20$ per cent of the requirement and equivalent to that of $5 \mathrm{oz}$. of bread. One pound of freshly lifted potatoes contains $135 \mathrm{mgm}$. of vitamin C, which is almost twice the day's needs; the average $\mathrm{C}$ content of potatoes makes a pound equivalent to $3 \mathrm{oz}$. of orange juice. Potatoes are rich in factors of the vitamin B-complex; $1 \mathrm{lb}$. is equiva* lent to $\frac{1}{8}$ pint of milk or 11 per cent of the day's needs of riboflavin ; to $4 \mathrm{oz}$. of meat or 36 per cent of the requirement of niacin or nicotinic acid. A pound of potatoes also probably contains as much vitamin $B_{6}$ and folic acid as $1 \mathrm{lb}$. of National bread, and as much pantothenic acid as one pint of milk.

The following table shows the average composition of potatoes :

\begin{tabular}{|c|c|c|c|c|c|c|}
\hline \multirow{4}{*}{$\begin{array}{l}\text { Calories .... } \\
\text { Calcium .... } \\
\text { Iron }\end{array}$} & \multicolumn{4}{|c|}{$\begin{array}{l}\text { Moisture } \\
\text { Protein } \\
\text { Carbohydrate }\end{array}$} & \multirow{2}{*}{$\begin{array}{r}78 \% \\
1.2 \% \\
16 \cdot 2 \% \\
\mathrm{r} 100 \mathrm{gm} .\end{array}$} & \\
\hline & & 70 & & per & & \\
\hline & ..... & $8 \mathrm{~m}$ & agm. & , &,$"$, & \\
\hline & & $0 \cdot 7$ & &,$"$ & ", & \\
\hline $\mathbb{V i t a m i n}_{\mathbf{V}} \mathbf{B}_{1}$ & .... & $40 \mathrm{I}$ & U. U. & $"$ & $"$, & \\
\hline $\begin{array}{l}\text { Vitamin } \\
\text { freshly lifted }\end{array}$ & $\ldots$ & & agm. & $"$ & ", ", & \\
\hline $\begin{array}{l}\text { freshly lifted } \\
\text { before Xmas }\end{array}$ & & $\begin{array}{l}30 \\
12\end{array}$ & 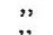 & $"$, & $", "$, & \\
\hline after Xmas & & 6 & ,", & ", & ", ", & \\
\hline Riboflavin & $\ldots .$. & 0.07 & ," & $"$ & $"$, & \\
\hline $\begin{array}{l}\text { Nicotinic acid } \\
\text { Vitamin }\end{array}$ & .... & $1 \cdot 4$ & $"$ & $"$ &,$"$, & \\
\hline Pantothenic ac & & 0.30 & ," & $"$ & ", ", & tentative values \\
\hline Folic acid & $\ldots$ & $0 \cdot 12$ & $"$, & ", & $", "$, & \\
\hline
\end{tabular}

At the present time the amount of potatoes purchased per head per day is less than $1 \mathrm{lb}$. This represents less than $13 \mathrm{oz}$. of edible potato. In Germany and in Ireland, more than $2 \mathrm{lb}$. a day are eaten as a national average.

\section{Farming in Great Britain}

"WAR Farming and After" was the title chosen by Lord Cornwallis for a paper to the Farmers' Club at the centenary meeting held in London on October 6. Using the first-hand knowledge gained as chairman of the Kent Agricultural Executive Committee, Lord Cornwallis outlined the problem facing British farming at the outbreak of war and showed how an ill-prepared and impoverished agriculture has risen to the occasion and achieved the remarkable result of 5 million acres gained for the plough in three years. Not only has this area been converted from grass or waste into arable, but also the standard of farming has been improved, and "the lovely land of England is beginning to look as if someone cared for it". The gain of human food has not been secured at the cost of the vitally important milk supply, for the dairy herds have been maintained in a remarkable manner, largely on home-grown foods. The organization that has brought this about-the county executive committees, their technical advisers, and all who worked on the land-has done a great service to Great Britain, and there is every indication that progress will continue. With farming on its feet and pulling its weight, all connected with the land have their minds fixed on the future of the industry after the present emergency has passed. The Government is pledged to maintain the stability of home farming until a permanent post-war policy can be put in action. This, as Lord Cornwallis said, implies a measure of control and the insistence on a certain standard of efficiency.

\section{Earthquakes in Guatemala}

THE United States Coast and Geodetic Survey in co-operation with Science Service and the Jesuit Seismological Association, on a basis of instrumental reports from 23 seismographic observatories, has determined the epicentres of recent earthquakes in Central America. The first was on August 6, 1942, at $23 \mathrm{~h} .37 \mathrm{~m}$. U.T., and the second on August 8, 1942. Both had epicentres near latitude $14 \cdot 4^{\circ} \mathrm{N}$., longitude $90.9^{\circ} \mathrm{W}$., which is to the south-west of Antigua. 